\title{
THE CAPABILITY OF FUNGI ISOLATED FROM MOLDY DWELLINGS TO PRODUCE TOXINS
}

\section{KAROLINA JEŻAK ${ }^{1}$, ANNA KOZAJDA ${ }^{1}$, MAŁGORZATA SOWIAK ${ }^{1}$, SŁAWOMIR BRZEŹNICKI르, MARZENA BONCZAROWSKA ${ }^{2}$, and IRENA SZADKOWSKA-STAŃCZYK ${ }^{1}$}

\author{
Nofer Institute of Occupational Medicine, Łódź, Poland \\ ${ }^{1}$ Department of Environmental Health Hazards \\ ${ }^{2}$ Department of Chemical Safety
}

\begin{abstract}
Objectives: The main objective was analysis and assessment of toxinogenic capabilities of fungi isolated from moldy surfaces in residential rooms in an urban agglomeration situated far from flooded areas in moderate climate zone. Material and Methods: The assessment of environmental exposure to mycotoxins was carried out in samples collected from moldy surfaces in form of scrapings and airborne dust from 22 moldy dwellings in winter season. In each sample 2 mycotoxins were analyzed: sterigmatocystin and roquefortine $\mathrm{C}$ produced by Aspergillus versicolor and Penicillium chrysogenum, respectively. Mycotoxins were analyzed by high-performance liquid chromatography (HPLC) in: scrapings from moldy surfaces, mixture of all species of fungi cultured from scrapings on microbiological medium (malt extract agar), pure cultures of Aspergillus versicolor and Penicillium chrysogenum cultured from scrapings on microbiological medium; mycotoxins in the indoor air dust were also analyzed. Results: The production of sterigmatocystin by individual strains of Aspergillus versicolor cultured on medium was confirmed for 8 of 13 isolated strains ranging 2.1-235.9 $\mu \mathrm{g} / \mathrm{g}$ and production of roquefortine $\mathrm{C}$ by Penicillium chrysogenum for 4 of 10 strains ranging 12.9-27.6 $\mu \mathrm{g} / \mathrm{g}$. In 11 of 13 samples of the mixture of fungi cultured from scrapings, in which Aspergillus versicolor was found, sterigmatocystin production was at the level of 3.1-1683.2 $\mu \mathrm{g} / \mathrm{g}$, whereas in 3 of 10 samples in which Penicillium chrysogenum occurred, the production of roquefortine $\mathrm{C}$ was $0.9-618.9 \mu \mathrm{g} / \mathrm{g}$. The analysis did not show in any of the tested air dust and scrapings samples the presence of analyzed mycotoxins in the amount exceeding the determination limit. Conclusions: The capability of synthesis of sterigmatocystin by Aspergillus versicolor and roquefortine $\mathrm{C}$ by Penicillium chrysogenum growing in mixtures of fungi from scrapings and pure cultures in laboratory conditions was confirmed. The absence of mycotoxins in scrapings and air dust samples indicates an insignificant inhalatory exposure to mycotoxins among inhabitants in moldy flats of urban agglomeration situated far from flooded territories. Int J Occup Med Environ Health 2016;29(5):823-836
\end{abstract}

Key words:

Indoor air, Mycotoxins, Molds, Residential environment, Sterigmatocystin, Roquefortine C

\section{INTRODUCTION}

Fungal spores in atmospheric air getting indoors are not capable to grow in housing conditions characterized by intact constructional balance. If, however, there is appropriate indoor temperature, humidity, and organic materials which can be a source of necessary foodstuffs, they settle fast in those premises [1-4]. High temperature in combination with flat flooding incidents and ineffective room ventilation that increase relative humidity of air and cause condensation of steam on surfaces may promote

The project was carried out under a grant financed by the National Science Center (Project No. 1754/B/P01/2010/39) entitled "Identification of the factors determining the degree of dampness and fungal contamination of flats in municipal agglomeration in the context of the impact on inhabitants' health," project manager: Prof. Irena Szadkowska-Stańczyk, M.D., Ph.D., and as a statutory task of Nofer Institute of Occupational Medicine financed from the subsidy by Ministry of Science and Higher Education (No. IMP 3.2/2012-2013) entitled "Identification and assessment of fungi toxicity isolated from the moldy dwellings," project manager: Karolina Jeżak, M.Sc. Received: February 3, 2015. Accepted: November 25, 2015.

Corresponding author: K. Jeżak, Nofer Institute of Occupational Medicine, Department of Environmental Health Hazards, św. Teresy 8, 91-348 Łódź, Poland (e-mail:kjezak@imp.lodz.pl). 
the growth of mold [4-7]. Fungi may develop on most of the building materials, carpets, leather, paper, and insulating materials [7-9]. Mold genera found on moldy surfaces usually include Penicillium, Aspergillus, Cladosporium, Acremonium and Alternaria, as well as genus Stachybotrys known for its high pathogenic activity [6,9-13].

Spores of mold or their fragments released into the ambient air from moldy surfaces may be harmful to human health when inhaled or in contact with the skin. The most prevalent adverse health effects of fungal exposure are: allergies, irritation of mucous membranes, respiratory symptoms, or toxic systemic effects [14-19]. The effects of mold on human health vary with the nature of a given species, its amount and products of its metabolism. Besides, the period of exposure to molds or their products as well as individual sensibility to respective species are important [14-19].

Toxic effects of fungi are connected with their products of secondary metabolism, known as mycotoxins. Individual mycotoxins differ in their toxic effects on organisms. Admittedly, they deteriorate the immune system and exhibit carcinogenic, mutagenic, embryotoxic, teratogenic, haemorrhagic, dermatotoxic, cytotoxic, neurotoxic activity, they also impair fertility [19-23]. Toxinogenic activity of individual species of molds is a property that becomes apparent in specific conditions of the substrate's humidity, temperature, availability of nutrients, and the presence of other (competitive) fungi [24,25]. Many fungi produce $\geq 2$ mycotoxins which may act synergically, enhancing their toxic effects [26,27].

Bioaerosol containing mycotoxins may be encountered in occupation and private life (in working and living environment). Occupational exposure is connected with processing and storing of crops, feeding of animals, production of foodstuffs, raising of animals and production of animal fodder, composting, biotechnology, work in such buildings as museums, libraries, archives and offices which are affected by moldiness [16,28-32]. Mycotoxins in environments other than occupational usually result from moldiness of damp residential buildings [24,25].

In relevant Polish literature, there are only few reports on toxinogenicity of molds present in domestic environment and attempts to evaluate the exposure of inhabitants of the moldy rooms to mycotoxins produced by molds present in such environments [7,33].

The main objective of the presented research was to analyze and assess toxinogenic capabilities of fungi isolated from moldy surfaces in residential rooms in a big urban agglomeration located in moderate climatic zone far away from flooded areas.

The additional objective of our research is to extend the existing knowledge by providing new information about the species of fungi isolated from moldy surfaces in flats and showing the capability of those microorganisms to produce mycotoxins.

\section{MATERIAL AND METHODS}

The studies were carried out in urban agglomeration in central Poland during 2011-2013. This publication presents the results obtained for 22 dwellings selected in a purposeful way from among 754 flats chosen by a simple random-selection method from the National Official Register of Territorial Division (Krajowy Rejestr Urzędowy Podziału Terytorialnego Kraju - TERYT), run by the Central Statistical Office of Poland (Główny Urząd Statystyczny - GUS), after informed written consent to participate in the study had been obtained from the inhabitants of the selected dwellings. The presence of developed mycelium on solid surfaces in the flat, as declared by inhabitants in a questionnaire survey conducted by trained interviewers during their visits to each of the selected flats served as the criterion of the purposeful selection.

To assess environmental exposure to mycotoxins in each of the tested dwellings, samples were collected in 2 ways: from moldy surfaces in form of scrapings, and from airborne dust. 
Mycotoxins were analyzed in the following material:

- scrapings from moldy surfaces (22 samples),

- mixture of all species of fungi cultured from scrapings on microbiological medium (22 samples),

- pure cultures of Aspergillus versicolor and Penicillium chrysogenum cultured from scrapings on microbiological medium (23 samples),

- indoor air dust from moldy rooms (22 samples).

Sampling was conducted in winter.

\section{Scrapings from moldy surfaces}

Scrapings in the form of mycelium fragments with a possibly thinnest layer of the base from moldy surfaces (mainly walls in flats) were scraped with a sterile scalpel to disposable sterile containers in each of the examined flats. Each time approx. $1.5 \mathrm{~g}$ of scrapings were collected.

\section{Culture and species identification of fungi from scrapings Culture of a fungi mixture}

Scraping samples, $0.5 \mathrm{~g}$ each, were placed in disposable sterile containers, and $10 \mathrm{ml}$ of phosphate buffer solution (PBS) (BTL, Poland) were added. The samples were shaken for 60 min with the shaking velocity of $420 \mathrm{rpm}$. A number of 10-fold dilutions were prepared from the resultant solutions and then, by superficial method, $1 \mathrm{ml}$ of eluates and their dilutions were inoculated on $140 \mathrm{~mm}$ plates with malt extract agar (MEA) medium (BTL, Poland) with added chloramphenicol (Galfarm, Poland) and streptomycin (Sigma-Aldrich, Germany) as well as oatmeal agar (OA) medium (Fluka Chemie, Switzerland) for identification of the Stachybotrys genus.

The samples were incubated for 14 days at $21^{\circ} \mathrm{C}$ and 50 $55 \%$ relative humidity (temperature and humidity selected similarly to the conditions prevalent in flats in winter according to actually measured values). After 7 days' culture, the colonies which grew on the plates were counted to determine the percentage share of identified species in respective samples. The mixtures of fungi which grew on the plates with the medium were subjected to further processing according to the procedure described below.

\section{Fungi species identification}

Fungi were identified according to morphologic traits of the colonies grown on diagnostic microbiological media and in microscopic picture, using literature data [34-38]. Yeasts were identified using analytical profile index (API) biochemical tests (bioMérieux, France).

\section{Pure cultures of Aspergillus versicolor and Penicillium chrysogenum}

Toxinogenic capabilities of molds isolated in our study were analyzed according to the literature data [39-42]. Two species of molds - Aspergillus versicolor and Penicillium chrysogenum - were selected for the studies, considering a high incidence of isolated potentially toxinogenic species in samples. The first of the molds specified above was found in 59\%, the latter in $45 \%$ of the samples collected from the moldy surfaces. Pure cultures of Aspergillus and Penicillium genera, which can produce the mycotoxins determined by us, were inoculated onto the plates with MEA medium (each strain on 3 plates) and incubated for 14 days at $21^{\circ} \mathrm{C}$ and approx. 50-55\% humidity. After 14 days, the inoculated pure cultures of mold with the medium were subjected to further processing according to the procedure described below.

\section{Sampling of airborne dust}

Airborne dust samples inside residential rooms were collected using the "aspirator and head with filter" sets. The set consisted of GilAir 5 (Sensidine, USA) aspirator, elastic hose and open measuring head (Two-Met, Poland), with $37 \mathrm{~mm}$ diameter and $0.7 \mu \mathrm{m}$ pore diameter GF/F glass fiber filter (Whatman, UK). The set was operated continuously at $21 /$ min air flow for $24 \mathrm{~h}$. Air dust samples were collected in a stationary way, at a height of approx. 1-1.2 m from the floor level. Filters with the collected dust were transferred to the laboratory and stored at $-20^{\circ} \mathrm{C}$ until analysis. 


\section{Analysis of mycotoxins}

Due to the limited budget for the study, only 2 types of mycotoxins were analyzed. Based on literature survey, mycotoxins most often synthesized by the above mentioned species of fungi were selected for analysis: sterigmatocystin (Aspergillus versicolor) and roquefortine C (Penicillium chrysogenum) $[33,40,42,43]$.

\section{Preparation of samples}

\section{Media with culture of molds}

Malt extract agar media (BTL, Poland) with mycelium which grew thereon (initial mixture of fungi and pure cultures of Aspergillus versicolor and Penicillium chrysogenum) were subjected to pasteurization $\left(85^{\circ} \mathrm{C}, 30 \mathrm{~min}\right)$ and comminution with a sterile scalpel. The samples were dried to a solid mass at $50^{\circ} \mathrm{C}$ for $40 \mathrm{~h}$, and 79:20:1 acetonitrile-water-acetic acid extraction mixture (POCH S.A., Poland) was added at $1 \mathrm{~g}$ sample: $4 \mathrm{ml}$ mixture ratio, subsequently the samples were extracted for 90 min with a KL-2 Multi-Purpose Shaker (Edmund Bühler $\mathrm{GmbH}$, Germany). Then the samples were centrifuged at $1000 \mathrm{~g}$ for $15 \mathrm{~min}$ (Laboratory Centrifuge 2-16K, Sigma, Germany); the resultant supernatant was subjected to chromatographic analysis. Dry mass of pure cultures of molds of Aspergillus versicolor and Penicillium chrysogenum species with the substrate ranged $1.2-1.7 \mathrm{~g}$, whereas the mass of fungal mixtures together with substrate was $1.1-1.7 \mathrm{~g}$.

\section{Scrapings}

Samples of scrapings in the amount of $1 \mathrm{~g}$ from each flat were subjected to pasteurization $\left(85^{\circ} \mathrm{C}, 30 \mathrm{~min}\right)$, extraction, centrifuging and chromatographic analysis in a similar way as the fungal samples described above.

\section{Airborne dust}

All filters were flushed with identical volume of the extraction mixture described above $(4 \mathrm{ml})$ and then the procedure followed exactly that applied for fungal samples as described above (see above: "Media with culture of molds").

\section{Chemicals and apparatus}

The following reagents were used for the analysis: standard sterigmatocystin, high-performance liquid chromatography (HPLC) grade acetonitrile (Sigma-Aldrich, USA), standard roquefortine $\mathrm{C}$ (LCG Standards, Germany), sodium acetate, acetic acid (POCH S.A., Poland), HPLC grade methanol (JT Baker, Netherlands) and water purified by using Milli-Q Plus Purification System (Merck Millipore, Germany). Qualitative and quantitative analyses were conducted using a Waters Alliance HPLC system equipped with Waters 2695 separation module, Waters 2996 PAD detector, Jet Stream column thermostat and Empower 2 software or Waters Breeze HPLC system equipped with Waters 1525 binary pump, Waters 717 plus autosampler, Waters 2487 dual absorbance detector, Jet Stream column thermostat and Breeze software. Chromatographic separations were carried out using C-18 Waters Symmetry $(150 \times 2.1 \mathrm{~mm}, 5 \mu \mathrm{m})$ analytical column eluted (gradient elution) with methanol:acetate buffer mobile phase.

\section{HPLC analysis}

Extracts of cultures of molds and scrapings were evaporated to dryness with gentle stream of nitrogen at $40^{\circ} \mathrm{C}$. Dry residue was dissolved in $1 \mathrm{ml}$ of acetonitrile and analyzed by means of HPLC method. Stock solutions of sterigmatocystin (ST) and roquefortine $\mathrm{C}(\mathrm{RC})$ were prepared in acetonitrile at concentrations $1 \mathrm{mg} / \mathrm{ml}$ and $0.1 \mathrm{mg} / \mathrm{ml}$, respectively. Calibration standards were prepared by subsequent dilution of ST and RC mixture (10 $\mu \mathrm{g} / \mathrm{ml}$ each). At least 6-point $0.2-10 \mu \mathrm{g} / \mathrm{ml}$ calibration curve was prepared. Determinations were conducted simultaneously at $247 \mathrm{~nm}$ and $326 \mathrm{~nm}$. Identifications of ST and RC were made by comparison of UV spectra (200-500 nm, Waters 2996) of standards and corresponding (retention time - RT) peaks of analyzed samples (Figure 1). In the case of samples for which spectral identification was not possible (low concentration of analyzed compounds), calculations of area under the curve (AUC) ratio of ST and RC standards 

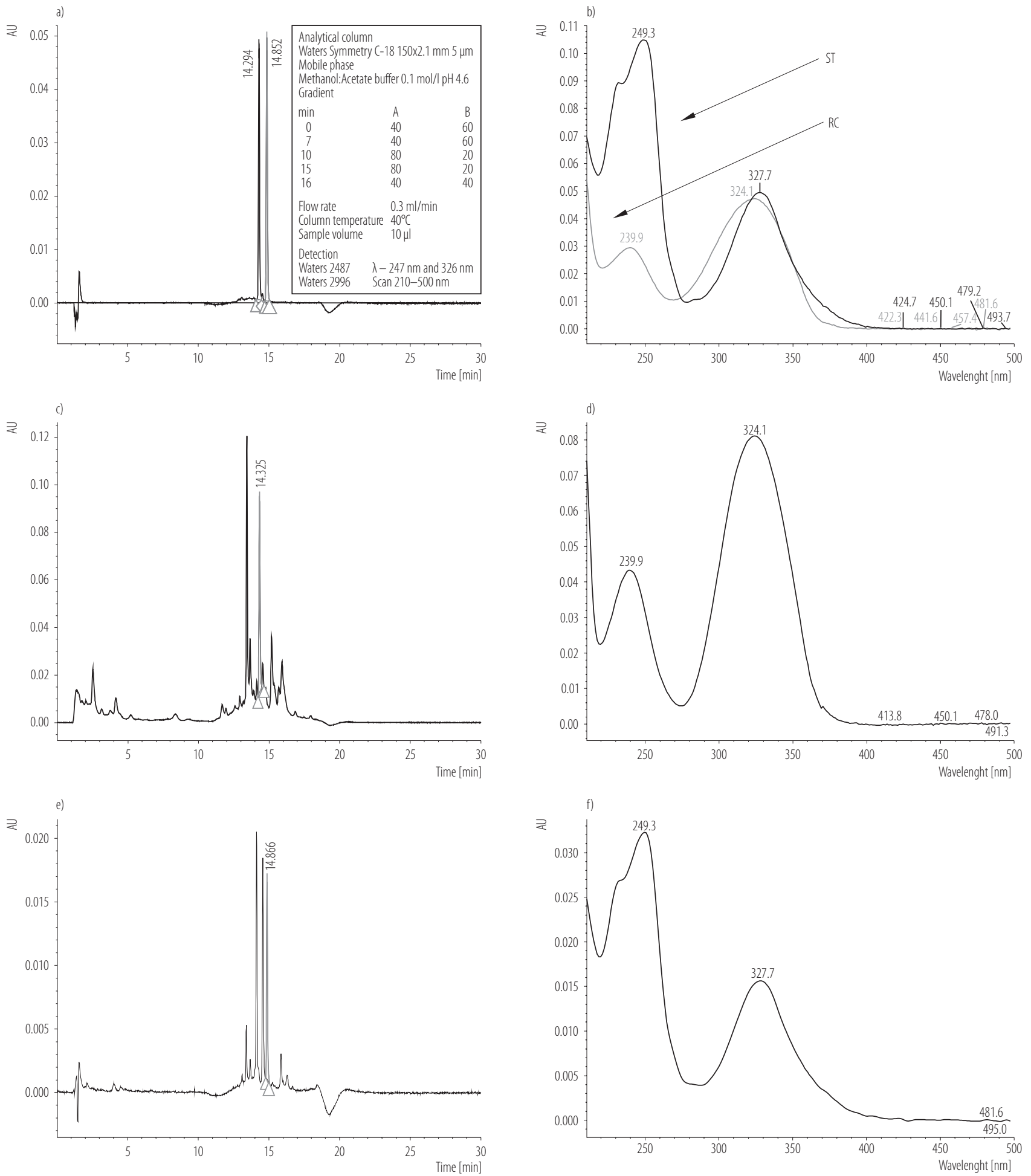

$\mathrm{AU}$ - absorbance units; ST - sterigmatocystin; RC - roquefortine $\mathrm{C}$.

Fig. 1. Chromatogram and UV spectra of a-b) sterigmatocystin and roquefortine $C$ standards and c-f) chromatograms of 2 samples with identified $\mathrm{c}-\mathrm{d}$ ) roquefortine $\mathrm{C}$ and $\mathrm{e}-\mathrm{f}$ ) sterigmatocystin 
Table 1. Area under the curve (AUC) ratio of roquefortine $\mathrm{C}$ and sterigmatocystin standards

\begin{tabular}{|c|c|c|c|c|c|}
\hline \multirow{2}{*}{$\begin{array}{c}\text { Compound concentration } \\
{[\mu \mathrm{g} / \mathrm{ml}]}\end{array}$} & \multicolumn{2}{|c|}{ AUC } & \multicolumn{2}{|c|}{ Ratio } & \multirow{2}{*}{$\mathrm{AM} \pm \mathrm{SD}(\mathrm{RSD})$} \\
\hline & $247 \mathrm{~nm}$ & $326 \mathrm{~nm}$ & $\mathrm{AUC}_{326} / \mathrm{AUC}_{247}$ & $\mathrm{AUC}_{247} / \mathrm{AUC}_{326}$ & \\
\hline Roquefortine $\mathrm{C}$ & & & & & $1.7 \pm 0.1(7.4)$ \\
\hline 0.2 & 3844 & 6231 & 1.6 & & \\
\hline 0.5 & 8655 & 12829 & 1.5 & & \\
\hline 1 & 16686 & 26880 & 1.6 & & \\
\hline 2 & 30276 & 52641 & 1.7 & & \\
\hline 5 & 72463 & 131099 & 1.8 & & \\
\hline 10 & 145813 & 259899 & 1.8 & & \\
\hline Sterigmatocystin & & & & & $2.1 \pm 0.2(7.2)$ \\
\hline 0.2 & 11646 & 6634 & & 1.8 & \\
\hline 0.5 & 26266 & 12680 & & 2.1 & \\
\hline 1 & 58632 & 28153 & & 2.1 & \\
\hline 2 & 116040 & 55465 & & 2.1 & \\
\hline 5 & 285156 & 135258 & & 2.1 & \\
\hline 10 & 584378 & 268999 & & 2.2 & \\
\hline
\end{tabular}

$\mathrm{AM}$ - arithmetic mean; SD - standard deviation; RSD - relative standard deviation.

and corresponding (RT) peaks measured at $247 \mathrm{~nm}$ and $326 \mathrm{~nm}$ were made. Concentration of ST or RC was calculated only for samples for which $\mathrm{AUC}_{247 / 326}$ ratio was within $\pm 10 \%$ of the mean value calculated for standards (Table 1).

\section{Statistics}

The results for isolated fungi are presented as a percentage which they constitute in the total concentration of fungi determined in the tested samples. The results of mycotoxin analysis were expressed in terms of micrograms per gram of the tested sample $(\mu \mathrm{g} / \mathrm{g})$ (scrapings, dry mass of cultured molds with substrate) and micrograms per cubic meter of air $\left(\mu \mathrm{g} / \mathrm{m}^{3}\right)$ (airborne dust).

\section{RESULTS}

Mycological analysis of the samples collected from moldy surfaces demonstrated the presence of molds and yeasts. Fourteen species of molds belonging to 8 genera and 3 species of yeasts belonging to 2 genera were detected. Considering the incidence of particular species of fungi, most frequently isolated on infected surfaces were: Aspergillus versicolor, Cladosporium cladosporioides, Penicillium chrysogenum, Ulocladium chartarum and Acremonium charticola. Among the cultured fungi, 4 genera of molds which allergize humans were found (Aspergillus, Penicillium, Cladosporium and Phoma), as well as 2 species capable to synthesize the analyzed mycotoxins hazardous for humans (Aspergillus versicolor, Penicillium chrysogenum) (Table 2).

Table 3 shows concentration of mycotoxins in various types of samples. While assessing the toxinogenicity of individual strains of Aspergillus versicolor cultured on the medium, the production of sterigmatocystin ranging 2.1-235.9 $\mu \mathrm{g} / \mathrm{g}$ was confirmed in conditions similar to the conditions prevailing in the tested flats for 8 of 13 isolated strains, while for Penicillium chrysogenum the production of roquefortine $\mathrm{C}$ ranging 12.9-27.6 $\mu \mathrm{g} / \mathrm{g}$ was confirmed 
Table 2. Genera/species of fungi isolated from samples of scrapings and composition

\begin{tabular}{|c|c|}
\hline Genus/species of fungi & $\begin{array}{c}\text { Composition of samples } \\
{[\%]}\end{array}$ \\
\hline \multicolumn{2}{|l|}{ Dwelling 1} \\
\hline Ulocladium chartarum & 38.9 \\
\hline Rhodotorula mucilaginosa 2 & 34.7 \\
\hline Cladosporium herbarum & 20.8 \\
\hline Aspergillus versicolor & 3.5 \\
\hline Penicillium chrysogenum & 1.4 \\
\hline Penicillium brevicompactum & 0.7 \\
\hline \multicolumn{2}{|l|}{ Dwelling 2} \\
\hline Aspergillus versicolor & 41.2 \\
\hline Cladosporium cladosporioides & 36.3 \\
\hline Acremonium charticola & 22.5 \\
\hline \multicolumn{2}{|l|}{ Dwelling 3} \\
\hline Cladosporium sphaerospermum & 82.3 \\
\hline Cladosporium cladosporioides & 17.7 \\
\hline \multicolumn{2}{|l|}{ Dwelling 4} \\
\hline Aspergillus versicolor & 27.3 \\
\hline Acremonium charticola & 27.3 \\
\hline Cladosporium cladosporioides & 18.2 \\
\hline Cladosporium herbarum & 9.1 \\
\hline Tritirachium sp. & 9.1 \\
\hline other fungi & 9.0 \\
\hline \multicolumn{2}{|l|}{ Dwelling 5} \\
\hline Aspergillus versicolor & 96.1 \\
\hline Cladosporium cladosporioides & 3.4 \\
\hline other fungi & 0.5 \\
\hline \multicolumn{2}{|l|}{ Dwelling 6} \\
\hline Cladosporium cladosporioides & 80.9 \\
\hline Penicillium chrysogenum & 19.0 \\
\hline \multicolumn{2}{|l|}{ Dwelling 7} \\
\hline Cladosporium cladosporioides & 75.5 \\
\hline Aspergillus versicolor & 20.4 \\
\hline Candida famata & 4.1 \\
\hline \multicolumn{2}{|l|}{ Dwelling 8} \\
\hline Cladosporium cladosporioides & 76.9 \\
\hline Aspergillus versicolor & 11.5 \\
\hline Penicillium chrysogenum & 7.7 \\
\hline Candida famata & 3.9 \\
\hline
\end{tabular}

Table 2. Genera/species of fungi isolated from samples of scrapings and composition - cont.

\begin{tabular}{|c|c|}
\hline Genus/species of fungi & $\begin{array}{c}\text { Composition of samples } \\
{[\%]}\end{array}$ \\
\hline \multicolumn{2}{|l|}{ Dwelling 9} \\
\hline Cladosporium cladosporioides & 95.2 \\
\hline Ulocladium chartarum & 2.4 \\
\hline Penicillium chrysogenum & 2.4 \\
\hline \multicolumn{2}{|l|}{ Dwelling 10} \\
\hline Cladosporium cladosporioides & 99.0 \\
\hline Acremonium charticola & 1.0 \\
\hline \multicolumn{2}{|l|}{ Dwelling 11} \\
\hline Cladosporium cladosporioides & 92.4 \\
\hline Aspergillus versicolor & 0.7 \\
\hline other fungi & 6.9 \\
\hline \multicolumn{2}{|l|}{ Dwelling 12} \\
\hline Geomyces pannorum & 97.7 \\
\hline Candida famata & 2.3 \\
\hline \multicolumn{2}{|l|}{ Dwelling 13} \\
\hline Acremonium charticola & 86.3 \\
\hline Cladosporium sphaerospermum & 13.7 \\
\hline \multicolumn{2}{|l|}{ Dwelling 14} \\
\hline Phoma sp. & 56.3 \\
\hline Ulocladium chartarum & 35.0 \\
\hline Aspergillus versicolor & 2.9 \\
\hline Penicillium brevicompactum & 1.9 \\
\hline Penicillium variabile & 1.0 \\
\hline other fungi & 2.9 \\
\hline \multicolumn{2}{|l|}{ Dwelling 15} \\
\hline Candida famata & 99.7 \\
\hline Penicillium chrysogenum & 0.3 \\
\hline \multicolumn{2}{|l|}{ Dwelling 16} \\
\hline Cladosporium cladosporioides & 74.0 \\
\hline Aspergillus versicolor & 26.0 \\
\hline \multicolumn{2}{|l|}{ Dwelling 17} \\
\hline Candida guilliermondi & 60.6 \\
\hline Aspergillus versicolor & 29.5 \\
\hline Penicillium chrysogenum & 5.3 \\
\hline Acremonium butyri & 4.5 \\
\hline \multicolumn{2}{|l|}{ Dwelling 18} \\
\hline Penicillium chrysogenum & 65.3 \\
\hline
\end{tabular}


Table 2. Genera/species of fungi isolated from samples of scrapings and composition - cont.

\begin{tabular}{lc}
\hline \multicolumn{1}{c}{ Genus/species of fungi } & $\begin{array}{c}\text { Composition of samples } \\
{[\%]}\end{array}$ \\
\hline Dwelling 18-cont. & \\
Ulocladium chartarum & 34.7 \\
Dwelling 19 & \\
Penicillium chrysogenum & 85.2 \\
Aspergillus versicolor & 5.6 \\
Cladosporium cladosporioides & 3.7 \\
Candida guilliermondi & 1.8 \\
other fungi & 3.7 \\
Dwelling 20 & \\
Penicillium chrysogenum & 81.8 \\
Aspergillus versicolor & 9.1 \\
Ulocladium chartarum & 6.1 \\
Phoma sp. & 3.0 \\
Dwelling 21 & \\
Cladosporium cladosporioides & 92.5 \\
Cladosporium sphaerospermum & 5.0 \\
Acremonium charticola & 2.5 \\
Dwelling 22 & \\
Cladosporium sphaerospermum & 47.9 \\
Penicillium chrysogenum & 22.6 \\
Aspergillus versicolor & 16.8 \\
Rhodotorula mucilaginosa 2 & 5.8 \\
Acremonium sp. & 3.2 \\
Ulocladium chartarum & 0.5 \\
other fungi & \\
\hline
\end{tabular}

for 4 of 10 isolated strains. Analysis of the mixture of fungi cultured from scrapings indicated that the number of molds coexisting on one infected surface varied from 1 to 6 species. In 11 of 13 samples of the mixture of fungi cultured from scrapings in which Aspergillus versicolor was found, the presence of sterigmatocystin was found at the level of 3.1-1683.2 $\mu \mathrm{g} / \mathrm{g}$, whereas in 3 of 10 samples in which mold of Penicillium chrysogenum species occurred, the production of roquefortine $\mathrm{C}$ was confirmed to vary from $0.9 \mu \mathrm{g} / \mathrm{g}$ to $618.9 \mu \mathrm{g} / \mathrm{g}$.

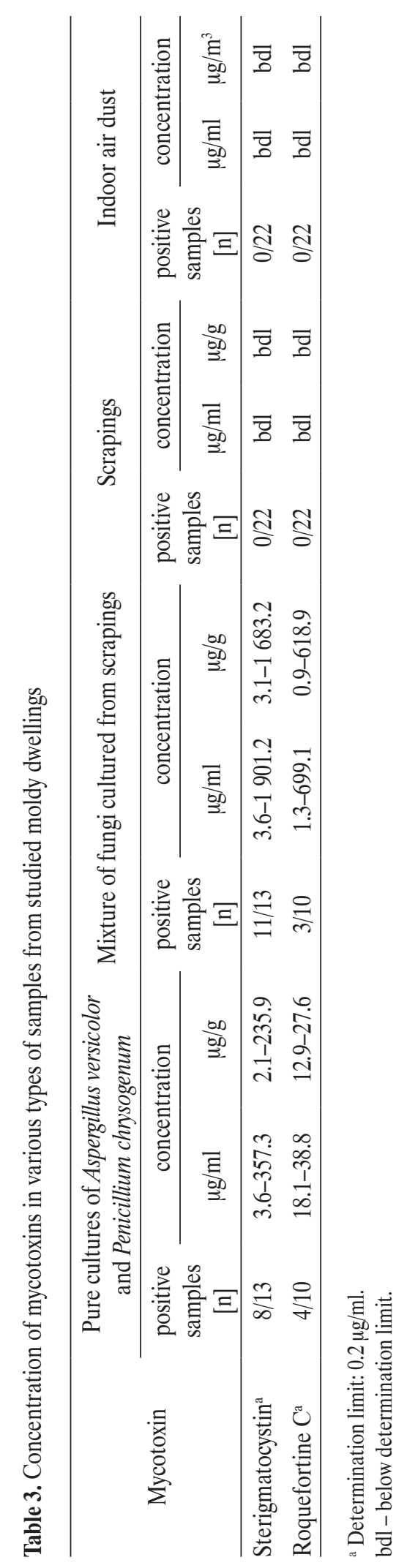


Air samples and scrapings from moldy surfaces collected in flats where isolated was any of the 2 potentially toxinogenic (Aspergillus versicolor or Penicillium chrysogenum) species of fungi, were analyzed for the presence of mycotoxins (sterigmatocystin and roquefortine C) using the HPLC method. The analysis did not show in any of the tested samples the presence of analyzed mycotoxins at concentration exceeding the limit of determination of the method $(0.2 \mu \mathrm{g} / \mathrm{ml})$.

\section{DISCUSSION}

The surfaces of moldy residential rooms may be infected with a number of species of molds and yeasts. Microbiological analysis in the study flats revealed 17 species of fungi which belong to 10 genera. Fungi of 5 genera: Cladosporium, Aspergillus, Penicillium, Ulocladium and Acremonium were isolated most frequently. Similar results were obtained by other authors [6,9-13,44].

The analysis showed that sterigmatocystin was confirmed to be present in 11 of 13 samples of mixtures of fungi cultured from the scrapings. Similar results were obtained by other authors. Gravesen et al. found sterigmatocystin in 19 of 23 samples of building materials infected in laboratory conditions with fungi collected from moldy Danish buildings [13]. Piontek isolated from building materials and other moldy surfaces 22 strains of Aspergillus versicolor, of which 19 in laboratory conditions synthesized sterigmatocystin at $0.03-534.38 \mathrm{mg} / \mathrm{kg}$ [33].

Gutarowska et al. examined the toxicity of fungi isolated from 34 tenement houses with visible signs of moldiness on different surfaces [7]. To check the toxinogenic activity of the collected Aspergillus and Penicillium genera, the authors cultured them on microbiological media and on the building materials inoculated with the mycelium in the laboratory. The molds cultured both on the media and on the building materials were the mycotoxin-producing ones. Molds of Aspergillus versicolor species produced sterigmatocystin on MEA medium and on building materials at $34000-94000 \mu \mathrm{g} / \mathrm{kg}$ and $82-480 \mu \mathrm{g} / \mathrm{kg}$, respectively. Molds belonging to Penicillium chrysogenum produced roquefortine $\mathrm{C}$ on MEA medium and on building materials at $2600 \mu \mathrm{g} / \mathrm{kg}$ and $100-1100 \mu \mathrm{g} / \mathrm{kg}$, respectively [7]. Analysis of scrapings and air samples did not indicate presence of studied mycotoxins at quantities exceeding the limit of determination of the method. Several other researchers determined the tested mycotoxins in samples of moldy materials or in the air of moldy buildings.

Vishwanath et al. tested the content of a number of different mycotoxins, including sterigmatocystin and roquefortine $\mathrm{C}$ in samples of different building materials collected from moldy buildings from Slovakia and Austria [45]. They demonstrated that of 14 samples of scrapings, in 10 samples sterigmatocystin was present at concentrations ranging 1.8-3900 $\mu \mathrm{g} / \mathrm{kg}$, while in 5 samples roquefortine $\mathrm{C}$ was found at concentrations $4.2-1000 \mu \mathrm{g} / \mathrm{kg}$ [45].

Tuomi et al. found sterigmatocystin in 19 of 79 samples of moldy materials collected from buildings in Finland [12]. Taubel et al. tested the content of mycotoxins in building materials collected from moldy residential buildings and public utility buildings. Similar to our results, they also found sterigmatocystin and roquefortine $\mathrm{C}$ (sterigmatocystin was found in 14 and roquefortine $\mathrm{C}$ in 5 of the total 42 samples) [46].

Polizzi et al. investigated the presence of mycotoxins in air and in scrapings collected from various types of surfaces infected with fungi in moldy residential buildings [30]. Of the investigated mycotoxins, sterigmatocystin and roquefortine $\mathrm{C}$ were determined at highest amounts. The analysis indicated that of 20 collected air samples, in 3 the presence of sterigmatocystin was determined in the amounts ranging $0.003-1.767 \mathrm{ng} / \mathrm{m}^{3}$, whereas in $1 \mathrm{sam}$ ple roquefortine $\mathrm{C}$ was found at $4 \mathrm{ng} / \mathrm{m}^{3}$, while of $52 \mathrm{sam}$ ples collected from moldy surfaces, in 19 samples sterigmatocystin was found at concentrations $0.06-778.4 \mathrm{ng} / \mathrm{cm}^{2}$ and 14 samples contained roquefortine $\mathrm{C}$ at concentrations ranging $0.106-7.2 \mathrm{ng} / \mathrm{cm}^{2}[30]$. 
The results presented above indicate that molds growing on various types of surfaces inside the buildings may constitute a source of mycotoxins in domestic environments. The studies conducted in buildings have not explained if airborne mycotoxins may be as dangerous for inhabitants as those getting into the organism with food.

However, it is important to note that exposure by inhalation of some mycotoxins can be more toxic than by ingestion, especially in the occupational environment $[31,47,48]$. The fungi species which synthesize mycotoxins were shown to locate these compounds in spores and hyphae [49-51], creating a risk to the people who inhale these morphological structures [52]. Each spore or hypha inhaled into the organism may constitute a source of one or more mycotoxins [43,53]. In the case of a high concentration of airborne spores and hyphae of fungi, especially those of the smallest size, they may be deposited in respirable area and systemic effects can be expected such as local respiratory lesions, absorption to circulatory and lymphatic systems and distribution to other organs [52].

Most of the quoted results obtained by other authors refer to the studies carried out in largely damp flats but, similarly as in our research, those not affected by flood. All studies, similarly to ours, were performed using the HPLC technique, therefore it is not clear why, in our research, we could not demonstrate the presence of mycotoxins in the air dust and scraping samples from flats. Perhaps this is due to climatic differences. The study which was most similar to ours and was carried out in the same agglomeration indicated a synthesis of mycotoxins by fungi collected from walls but, as in our study, only in cultures grown in laboratory conditions [7]. Sterigmatocystin, produced by molds of Aspergillus genus (mainly Aspergillus versicolor species) is a toxic secondary metabolite whose structure resembles that of aflatoxin, a precursor of its biosynthesis [21,54]. Similarly to aflatoxin and ochratoxin $\mathrm{A}$, it inhibits protein synthesis at the level of transcription and translation.
Changes in DNA resulting from the effects of sterigmatocystin lead to the immune system deficiency, and thereby to increased incidence of infectious diseases. Furthermore, this mycotoxin exhibits carcinogenic properties [52]. The other mycotoxin analyzed in this article, roquefortine $\mathrm{C}$, produced by a number of species belonging to genus Penicillium, exhibits neurotoxic effects [40].

Although the analysis did not show the presence of sterigmatocystin or roquefortine $\mathrm{C}$ in the air or in scrapings from infected surfaces, they were shown to be present in the mixture of fungi cultured from the scrapings. This confirms that the strains of Aspergillus versicolor and Penicillium chrysogenum classified as toxinogenic exhibit this property in laboratory conditions when cultured on MEA medium.

Literature indicates that toxinogenic activity of fungi is to some extent connected with the presence of other species in the environment, which compete for access to foodstuffs [55,56]. Besides, indispensable for synthesis of mycotoxins by fungi are appropriate climatic conditions (temperature, humidity) and, first of all, access to medium rich in organic substances $[24,25,56]$.

Please note that the results of our studies indicated the presence of mycotoxins in the culture grown in laboratory conditions, i.e., when optimum conditions for fungi growth were provided. The same mixture of fungi species was present on the walls in the examined flats (scrapings) but the laboratory analysis did not show any mycotoxins in them, which could result from the lack of conditions proper for mycotoxin synthesis. According to literature, there are, though scarcely, strains which produce far fewer mycotoxins when growing on building materials, as compared to growing on microbiological media. There are also potentially toxinogenic strains which have lost their capability to produce mycotoxins in natural conditions and these are capable to produce them only in specific laboratory conditions $[53,56]$. 
The results of our research demonstrate that a change in the conditions prevailing in the flat that affect fungal metabolism may result in production of mycotoxins. To avoid contamination of indoor air and surfaces by mycotoxins, first of all, it is necessary to prevent the growth of fungi; therefore, the conditions such as relative humidity, substrate humidity, temperature, availability of nutrients should be permanently monitored.

The presented results enrich the existing knowledge about the diversity of fungi species isolated from moldy surfaces in the flats not affected by flood and confirm the practical capabilities of some of these microorganisms to produce mycotoxins.

Although the research is limited by a low number of collected and analyzed samples, yet the results, consistent with similar studies reported by other authors, allow to formulate the following conclusions.

\section{CONCLUSIONS}

Fungi representing 17 species belonging to 10 genera were identified in moldy flats. Molds of the following genera were predominant on the infected surfaces: Aspergillus, Cladosporium, Penicillium, Ulocladium and Acremonium.

Among the identified fungi, there were genera which may exhibit the capability to produce mycotoxins harmful to human health (Aspergillus and Penicillium). The research confirmed the occurrence, on the tested surfaces, of strains of Aspergillus versicolor genus which can produce sterigmatocystin and strains of Penicillium chrysogenum genus capable of producing roquefortine $\mathrm{C}$.

The capability for synthesis of sterigmatocystin by molds of genus Aspergillus versicolor and roquefortine $\mathrm{C}$ by Penicillium chrysogenum growing in mixtures of fungi from scrapings and pure cultures in laboratory conditions was confirmed.

The absence of mycotoxins in scrapings and air dust samples indicates an insignificant inhalatory exposure to mycotoxins in case of people who live in moldy flats of urban agglomerations situated far from flooded territories, but in which some specific conditions (such as substrate humidity, temperature, availability of nutrients) can promote higher production of mycotoxins. To avoid synthesis of, and contamination by mycotoxins, the conditions specified above should be monitored.

\section{REFERENCES}

1. Nielsen KF, Holm G, Uttrup LP, Nielsen PA. Mould growth on building materials under low water activities. Influence of humidity and temperature on fungal growth and secondary metabolism. Int Biodeterior Biodegradation. 2004;54(4): 325-36, http://dx.doi.org/10.1016/j.ibiod.2004.05.002.

2. Cho SJ, Ramachandran G, Banerjee S, Ryan AD, Adgate JL. Seasonal variability of culturable fungal genera in the house dust of inner-city residences. J Occup Environ Hyg. 2008;5(12):780-9, http://dx.doi.org/10.1080/1545962080 2490267.

3. Krajewska-Kułak E, Łukaszuk C, Gniadek A, Macura AB, van Damme-Ostapowicz K, Lewko J, et al. [Air pollution in dwellings, with particular emphasis on the role of fungi]. Mikol Lek. 2011;18(3):135-9. Polish.

4. Żukiewicz-Sobczak W, Sobczak P, Imbir K, Krasowska E, Zwoliński J, Horach A, et al. [Fungal hazards in buildings and flats - Impact on the human organism]. Med Ogolna Nauki Zdr. 2012;18(2):141-6. Polish.

5. Chew GL, Rogers C, Burge HA, Muilenberg ML, Gold DR. Dustborne and airborne fungal propagules represent a different spectrum of fungi with differing relations to home characteristics. Allergy. 2003;58(1):13-20, http://dx.doi.org/10.1034/ j.1398-9995.2003.00013.x.

6. Gutarowska B, Piotrowska M. Methods of mycological analysis in buildings. Build Environ. 2007;42(4):1843-50, http:// dx.doi.org/10.1016/j.buildenv.2006.02.015.

7. Gutarowska B, Sulyok M, Krska R. A study of the toxicity of moulds isolated from dwellings. Indoor Built Environ. 2010;19(6):668-75, http://dx.doi.org/10.1177/1420326X1 0378803 . 
8. Gutarowska B. [Building materials as a substrate for filamentous fungi growth]. In: Gutarowska B. [Filamentous fungi colonizing building materials. Growth and production of mycotoxin and allergens] [dissertation]. Sci Bull Tech Univ Lodz. 2010;1074:37-41. Polish.

9. Andersen B, Frisvad JC, Søndergaard I, Rasmussen IS, Larsen LS. Associations between fungal species and water-damaged building materials. Appl Environ Microbiol. 2011;77(12):4180-8, http://dx.doi.org/10.1128/AEM. 02513-10.

10. Levinskaitė L, Paškevičius A. Fungi in water-damaged buildings of Vilnius Old City and their susceptibility towards disinfectants and essential oils. Indoor Built Environ. 2013;22(5):766-75, http://dx.doi.org/10.1177/1420326X 12458514 .

11. Gottschalk C, Bauer J, Meyer K. Determination of macrocyclic trichothecenes in mouldy indoor materials by LCMS/MS. Mycotoxin Res. 2006;22(3):189-92, http://dx.doi. org/10.1007/BF02959275.

12. Tuomi T, Reijula K, Johnsson T, Hemminki K, Hintikka EL, Lindroos O, et al. Mycotoxins in crude building materials from water-damaged buildings. Appl Environ Microbiol. 2000;66(5):1899-904, http://dx.doi.org/10.1128/ AEM.66.5.1899-1904.2000.

13. Gravesen S, Nielsen PA, Iversen R, Nielsen KF. Microfungal contamination of damp buildings - Examples of risk constructions and risk materials. Environ Health Perspect. 1999;107 Suppl 3:505-8.

14. Wiszniewska M, Walusiak J, Gutarowska B, Żakowska Z, Pałczyński C. [Moulds - Occupational and environmental hazards]. Med Pr. 2004;55(3):257-66. Polish.

15. Bush RK, Portnoy JM, Saxon A, Terr AI, Wood RA. The medical effects of mold exposure. J Allergy Clin Immunol. 2006;117(2):326-33, http://dx.doi.org/10.1016/j.jaci. 2005.12.001.

16. Terr AI. Sick building syndrome: Is mould the cause? Med Mycol. 2009;47 Suppl 1:217-22, http://dx.doi.org/10.1080/ 13693780802510216.
17. Mendell MJ, Mirer AG, Cheung K, Tong M, Douwes J. Respiratory and allergic health effects of dampness, mold, and dampness-related agents: A review of the epidemiologic evidence. Environ Health Perspect. 2011;119(6):748-56, http:// dx.doi.org/10.1289/ehp.1002410.

18. Keall MD, Crane J, Baker MG, Wickens K, HowdenChapman P, Cunningham M. A measure for quantifying the impact of housing quality on respiratory health: A crosssectional study. Environ Health. 2012;11:33, http://dx.doi. org/10.1186/1476-069X-11-33.

19. Boonen J, Malysheva SV, Taevernier L, di Mavungu JD, de Saeger S, de Spiegeleer B. Human skin penetration of selected model mycotoxins. Toxicology. 2012;301(1-3):21-32, http://dx.doi.org/10.1016/j.tox.2012.06.012.

20. Curtis L, Lieberman A, Stark M, Rea W, Vette M. Adverse health effects of indoor molds. J Nutr Environ Med. 2004;14(3):261-74, http://dx.doi.org/10.1080/13590840 400010318.

21. Bünger J, Westphal G, Mönnich A, Hinnendahl B, Hallier E, Müller M. Cytotoxicity of occupationally and environmentally relevant mycotoxins. Toxicology. 2004;202(3):199-211, http://dx.doi.org/10.1016/j.tox.2004.05.007.

22. Jarvis BB, Miller JD. Mycotoxins as harmful indoor air contaminants. Appl Microbiol Biotechnol. 2005;66(4):367-72, http://dx.doi.org/10.1007/s00253-004-1753-9.

23. Karunasena E, Larrañaga MD, Simoni JS, Douglas DR, Straus DC. Building-associated neurological damage modeled in human cells: A mechanism of neurotoxic effects by exposure to mycotoxins in the indoor environment. Mycopathologia. 2010;170(6):377-90, http://dx.doi.org/10.1007/ s11046-010-9330-5.

24. Nielsen KF, Gravesen S, Nielsen PA, Andersen B, Thrane U, Frisvad JC. Production of mycotoxins on artificially and naturally infested building materials. Mycopathologia. 1999;145(1):43-56, http://dx.doi.org/10.1023/A:10070 38211176.

25. Ammann HM. [Is fungal contamination indoor is dangerous for health?]. In: Grajewski J, editor. [Mycotoxins and molds. 
Hazards for humans and animals]. Bydgoszcz: Kazimierz Wielki University Publishing House; 2006. p. 35-46. Polish.

26. Hussein HS, Brasel JM. Toxicity, metabolism, and impact of mycotoxins on humans and animals. Toxicology. 2001;167(2):101-34, http://dx.doi.org/10.1016/S0300483X(01)00471-1.

27. Zyska B. [Biology of microorganisms]. In: Zyska B, Żakowska Z, editors. [Microbiology of materials]. Łódź: Lodz University of Technology Publishing House; 2005. p. 61-5. Polish.

28. Tangni EK, Pussemier L. Ergosterol and mycotoxins in grain dusts from 14 Belgian cereal storages: A preliminary screening survey. J Sci Food Agric. 2007;87(7):1263-70, http:// dx.doi.org/10.1002/jsfa.2838.

29. Soroka PM, Cyprowski M, Szadkowska-Stańczyk I. [Occupational exposure to mycotoxins in various branches of industry]. Med Pr. 2008;59(4):333-45. Polish.

30. Polizzi V, Delmulle B, Adams A, Moretti A, Susca A, Picco AM, et al. JEM Spotlight: Fungi, mycotoxins and microbial volatile organic compounds in mouldy interiors from water-damaged buildings. J Environ Monit. 2009;11(10):184958, http://dx.doi.org/10.1039/b906856b.

31. Viegas S, Veiga L, Figueredo P, Almeida A, Carolino E, Sabino R, et al. Occupational exposure to aflatoxin $\mathrm{B}_{1}$ : The case of poultry and swine production. World Mycotoxin J. 2013;6(3):309-15, http://dx.doi.org/10.3920/WMJ2012.1531.

32. Viegas S, Veiga L, Malta-Vacas J, Sabino R, Figueredo P, Almeida A, et al. Occupational exposure of aflatoxin $\left(\mathrm{AFB}_{1}\right)$ in poultry production. J Toxicol Environ Health. 2012;75(22/23):1330-40, http://dx.doi.org/10.1080/15287394. 2012.721164.

33. Piontek M. Strains of Aspergillus versicolor Tiraboschi synthesizing sterigmatocystin and the differentiation of mycotoxic risk dependent on their productivity in housing buildings. Mycotoxin Res. 2007;23(1):34-8, http://dx.doi.org/10.1007/ BF02946022.

34. Fassatiova O. [Microscopic fungi in technical microbiology]. Warszawa: Wydawnictwa Naukowo-Techniczne; 1983. Polish.
35. Flanningan B, Samson RA, Miller JD, editors. Microorganisms in home and indoor work environments. Diversity, health impacts, investigation and control. New York: CRC Press LLC; 2001.

36. Klich MA. Identification of common Aspergillus species. Utrecht: Centraalbureau voor Schimmelcultures; 2002.

37. Larone DH. Medically important fungi. A guide to identification. 4th ed. Washington, D.C.: ASM Press; 2002.

38. Pitt JI. A laboratory guide to common Penicillium species. 3rd ed. North Ryde, New South Wales: Commonwealth Scientific and Industrial Research Organization, Australia; 2000.

39. Singh J. Toxic moulds and indoor air quality. Indoor Built Environ. 2005;14(3-4):229-34, http://dx.doi.org/10.1177/14 $20326 X 05054015$.

40. Frisvad JC, Smedsgaard J, Larsen TO, Samson RA. Mycotoxins, drugs and other extrolites produced by species in Penicillium subgenus Penicillium. In: Samson RA, Frisvad JC, editors. Penicillium subgenus Penicillium: New taxonomic schemes, mycotoxins and other extrolites, Utrecht: Centraalbureau voor Schimmelcultures; 2004. p. 201-41.

41. Nielsen KF. Mycotoxin production by indoor molds. Fungal Genet Biol. 2003;39(2):103-17, http://dx.doi.org/10.1016/ S1087-1845(03)00026-4.

42. Engelhart S, Loock A, Skutlarek D, Sagunski H, Lommel A, Färber H, et al. Occurrence of toxigenic Aspergillus versicolor isolates and sterigmatocystin in carpet dust from damp indoor environments. Appl Environ Microbiol. 2002;68(8):3886-90, http://dx.doi.org/10.1128/AEM.68.8.38 86-3890.2002.

43. De la Campa R, Seifert K, Miller JD. Toxins from strains of Penicillium chrysogenum isolated from buildings and other sources. Mycopathologia. 2007;163(3):161-8, http:// dx.doi.org/10.1007/s11046-007-0091-8.

44. Reboux G, Bellanger AP, Roussel S, Grenouillet F, Sornin S, Piarroux R, et al. Indoor mold concentration in Eastern France. Indoor Air. 2009;19(6):446-53, http://dx.doi.org/ 10.1111/j.1600-0668.2009.00598.x. 
45. Vishwanath V, Sulyok M, Labuda R, Bicker W, Krska R. Simultaneous determination of 186 fungal and bacterial metabolites in indoor matrices by liquid chromatography/tandem mass spectrometry. Anal Bioanal Chem. 2009;395(5):135572, http://dx.doi.org/10.1007/s00216-009-2995-2.

46. Täubel M, Sulyok M, Vishwanath V, Bloom E, Turunen M, Järvi K, et al. Co-occurrence of toxic bacterial and fungal secondary metabolites in moisture-damaged indoor environments. Indoor Air. 2011;21(5):368-75, http://dx.doi. org/10.1111/j.1600-0668.2011.00721.x.

47. Degen GH. Tools for investigating workplace-related risks from mycotoxin exposure. World Mycotoxin J. 2011;4:31527, http://dx.doi.org/10.3920/WMJ2011.1295.

48. Degen GH. The challenge to assess workplace related risks from mycotoxin exposure (guest editorial). Mycotoxin Res. 2008;24(3):i-ii, http://dx.doi.org/10.1007/BF03032336.

49. Flannigan B, Miller JD. Microbial growth in indoor environments. In: Flannigan B, Samson RA, Miller JD, editors. Microorganisms in home and indoor work environments: Diversity, health impacts, investigation and control. London and New York: Taylor \& Francis Inc.; 2001. p. 35-67, http:/ dx.doi.org/10.4324/9780203302934.

50. Menetrez MY, Foarde KK. Emission exposure model for the transport of toxic mold. Indoor Built Environ. 2004;13(1): 75-82, http://dx.doi.org/10.1177/1420326X04041038.
51. Grajewski J, Twarużek M. [The healthy aspects of the influence of moulds and mycotoxins]. Alergia. 2004;21(3):45-9. Polish.

52. Ammann HM. Mycotoxins in indoor environments. Mycotoxin Res. 2005;21(3):157-63, http://dx.doi.org/10.1007/ BF02959254.

53. Cabral JP. Can we use indoor fungi as bioindicators of indoor air quality? Historical perspectives and open questions. Sci Total Environ. 2010;408(20):4285-95, http://dx.doi. org/10.1016/j.scitotenv.2010.07.005.

54. Barnes SE, Dola TP, Bennett JW, Bhatnagar D. Synthesis of sterigmatocystin on a chemically defined medium by species of Aspergillus and Chaetomium. Mycopathologia. 1994;125(3):173-8, http://dx.doi.org/10.1007/BF01146523.

55. Chełkowski J. [Mycotoxins, toxinogenic fungi and mycotoxicosis]. Poznań: Wydawnictwo Instytutu Genetyki Roślin PAN; 2010. p. 4. Polish.

56. Gutarowska B. [Mycotoxins]. In: Gutarowska B. [Filamentous fungi colonizing building materials. Growth and production of mycotoxin and allergens] [dissertation]. Sci Bull Tech Univ Lodz. 2010;1074:23-7. Polish.

This work is available in Open Access model and licensed under a Creative Commons Attribution-NonCommercial 3.0 Poland License - http://creativecommons.org/ licenses/by-nc/3.0/p1/deed.en. 